\title{
PREDIKSI EROSI PADA BERBAGAI POLA USAHA TANI DI DESA \\ KABIRAAN KECAMATAN ULUMANDA KABUPATEN MAJENE \\ Oleh \\ Qaizar K
}

\section{Dosen Fakultas Pertaniaan Universitas Satria Makassar}

\begin{abstract}
ABSTRAK
Penelitian ini bertujuan untuk (1) memprediksi besarnya erosi yang terjadi pada berbagai pola usaha tani masyarakat, (2) menentukan erosi yang diperkenankan, dan (3) merumuskan tindakan konservasi tanah dan air pada setiap pola usaha tani.

Penelitian ini dilaksanakan di Desa Kabiraan Kecamatan Ulumanda Kabupaten Majene. Pengumpulan data dilakukan melalui observasi dan wawancara. Metode yang digunakan dalam memprediksi besarnya erosi adalah persamaan umum kehilangan tanah (metode USLE).

Hasil penelitian menunjukkan bahwa besarnya laju erosi yang terjadi pada enam pola usaha tani adalah 83,7 ton per hektar per tahun. Berdasarkan keenam pola usaha tani tersebut diperoleh besarnya laju erosi pada setiap bentuk pola, yaitu (1) jagung, kacang tanah 29,16 ton per hektar per tahun, (2) cengkeh, polio, cempaka,kemiri, durian, tippulu, langsat,semak 16,37 ton/ha/tahun, (3) jagung, gamal, 4,34 ton/ha/tahun. Besarnya erosi yang terjadi pada berbagai pola usaha tani masih melebihi besarnya erosi yang diperkenankan.Untuk itu diperlukan upaya-upaya untuk menekan laju erosi dengan melakukan praktek konservasi tanah dan bentuk penggunaan lahan yang memberikan perlindungan atau penutupan lahan yang lebih baik.
\end{abstract}

\section{PENDAHULUAN}

\section{A. Latar Belakang}

Kegiatan konservasi dilahan konstruktif, dapat meningkatkan fungsi lahan untuk berproduksi secara lestari, sehingga potensinya dapat dioptimalkan sebagai sumber pendapatan keluarga tani di pedesaan. Menurut Notohadiprawita (1988), lahan kering marginal yang berstatus kritis dicirikan oleh solum tanah yang dangkal,kemiringan lereng curam, tingkat erosi telah lanjut, kandungan bahan organik sangat rendah, serta banyak singkapan batuan di permukaan.

Kondisi demikian umumnya terdapat di wilayah desa tertinggal dan sebagian besar dikelola oleh petani miskin yang tidak mampu melaksanakan upaya-upaya konservasi, sehingga kondisinya makin lama makin memburuk (Karama dan Abdurrachman, 1995). 
Desa Kabiraan adalah salah satu desa dari empat desa yang ada dalam wilayah Kecamatan Ulumanda Kabupaten Majene dengan panjang pantai $8 \mathrm{~km}$, terletak dipesisir utara dengan luas wilayah $7.500 \mathrm{Ha}$. Desa Kabiraan mempunyai lahan usaha tani seluas $477,5 \mathrm{Ha}$ dengan jumlah produksi 588,2 ton/tahun, lahan-lahan usaha tani tersebut masih sangat kurang melakukan tindakan-tindakan konservasi (kondisi fisik,kondisi vegetasi). Seandainya praktek tindakan-tindakan khusus konservasi telah dilakukan jauh sebelumnya, tentunya lahan-lahan usahatani tersebut telah memiliki nilai produktivitas yng tinggi dan meningkatkan jumlah produksi yang telah di capai.

Tiga dusun di Desa Kabiraan memiliki variasi tingkat kemiringan lahan, dalam kondisi seperti ini dengan iklim yang sama akan menghasilkan jumlah erosi dan aliran menghasilkan jumlah erosi dan aliran permukaan yang berbeda. Dalam hal ini lahan yang memiliki tingkat kemiringan yang randah, dengan penutupan tajuk yang rapat serta didukung oleh tindakan khusus konservasi tentunya akan menghasilkan jumlah erosi yang rendah.

Pelestarian produktivitas lahan usahatani ini dapat dilakukan melalui suatu tindakan konservasi yang dapat menjamin kelstarian pengolahan usahatani. Dalam merumuskan tindakan konservasi yang dapat menjamin kelestarian pengelolaan usahatani dibutuhkan data kondisi sistem lahan yang ada saat ini,salah satu di antaranya adalah besarnya laju erosi yang terjadi. Dengan adanya data erosi,maka dapat dirumuskan suatu tindakan konservasi yang berorientasi kepada konservasi tanah. Data erosi dimaksud selain dapat dijadikan dasar dalam membuat rumusan tindakan konservasi juga dapat dijadikan acuan dalam menentukan skala prioritas terhadap penanganan lahan-lahan usahatani yang berpotensi menimbulkan erosi yang lebih besar yang lebih besar.

Berdasarkan uraian-uraian tersebut,maka dalam penelitian ini dilakukan analisis besarnya laju erosi yang terdapat pada berbagai pola usahatani di Desa Kabiraan dengan menggunakan metode USLE (Universal Soil Loss Equation). Data erosi indeks bahaya erosi dan nilai kesenjangan yang terdapat pada berbagai pola usahatani dapat dijadikan data dasar dalam membuat suatu perencanaan pengelolaan lahan usaha tani secara menyeluruh dan lebih khusus dalam hal perencanaan pola penggunaan/pemanfaatan lahan usahatani dan arahan dalam melakukan tindakan konservasi tanah di Desa Kabiraan.

\section{B. Rumusan Masalah}

Berbagai pola usahatani dalam wilayah Desa Kabiraan yang kurang memperhatikan kaidah-kaidah konservasi tanah dan ditunjang oleh kondisi biofisik wilayah seperti ; curah hujan yang tinggi, Sifat tanah yang peka erosi, topografi yang curam akan mempercepat laju erosi. Oleh karena itu diperlukan data besarnya erosi 
aktual dan erosi diperkenankan, untuk dipergunakan dalam merumuskan tindakan konservasin pengelolaan usahatani yang mendukung konservasi tanah dan air.

\section{Tujuan Penelitian}

Adapun tujuan dalam penelitian ini adalah :

1. Memprediksi erosi aktual dan menentukan erosi yang diperkenankan pada berbagai pola usahatani di desa Ulumanda Kabupaten Majene.

2. Merumuskan tindakan konservasi tanah dan air pada setiap pola usahatani.

\section{Manfaat Penelitian}

Hasil penelitian ini diharapkan dapat bermanfaat sebagai :

1. Bahan informasi dan pertimbangan bagi masyarakat petani maupun pemerintah daerah dalam menetapkan kebijakan pengembangan pola usahatani yang berkelanjutan yang pada akhirnya dapat meningkatkan kesejahteraan masyarakat petani di Desa Ulumanda Kabupaten Majene.

2. Sebagai bahan informasi dalam memformulasi upaya-upaya rehabilitasi pada pola usahatani lahan kering di Desa Ulumanda Kabupaten Majene.

\section{METODE PENELITIAN}

\section{A. Tempat Dan Waktu Penelitian}

Penelitian ini dilaksanakan di empat dusun dalam wilayah Desa Kabiraan yang merupakan areal usahatani masyarakat, Terletak di Kecamatan Ulumanda, Kabupaten Majene, Propinsi Sulawesi Barat. Pelaksanaan penelitian pada bulan Agustus sampai dengan oktober 2009.

\section{B. Pendekatan Penelitian}

Untuk mencapai tujuan penelitian yang telah ditetapkan, maka kegiatan yang dilaksanakan pada tahap persiapan adalah sebagai berikut :

1. Observasi berbagai pola usahatani di Desa Kabiraan, Kabupaten Majene sebagai bakal objek penelitian.

2. Menetapkan enam pola usahatani sebagai objek penelitian.

3. Pengumpulan data sekunder meliputicurah hujan; jumlah curah hujan, jumlah hari, hari hujan, curah hujan maksimun.

4. Pengumpulan peta-peta berupa, peta administrasi wilayah, peta geologi/jenis tanah, peta penutupan lahan, peta kelas kemiringan lereng.

Selanjutnya pendekatan analisis untuk memprediksi besarnya erosi dan menyusun rumusan tindakan konservasi tanah dan air yang digunakan tahapantahapan utama sebagai berikut :

1. Analisis curah hujan untuk menentukan nilai erosivitas hujan. 
2. Analisis sifat-sifat setiap jenis tanah untuk menentukan nilai erodibilitas.

3. Ananlis kemiringan lereng dan panjang lereng untuk menentukan nilai faktor panjang lereng dan kemiringan lereng (LS).

4. Analisis kondisi berbagai pola usahatani dan praktek konservasi.

5. Analisis tingkat kehilangan tanah dengan pendekatan metode USLE.

6. Analisis erosi yang diperkenankan

7. Analisis kesenjangan (GAP).

\section{Pelaksanaan penelitian}

\section{Pengumpulan Data}

Untuk menunjang urutan perhitungan dan analisis berbagai parameter sesuai dengan tujuan penelitian, maka diperlukan data dasar yang diperoleh dari pengamatan langsung di alpangan maupun dari data sekunder. Data dasar yang diperlukan untuk menggambarkan kondisi lahan pola usahatani untuk keperluan perhitungan atau analisis meliputi : lokasi, derajat kemiringan, jenis tanah, kedalaman tanah, geologi dan batuan induk.

Data klimatologi (curah hujan) diperoleh dari rekaman stasiun penakar hujan yang yang berada dalam/sekitar wilayah penelitian. Data curah hujan diolah sesuai dengan desain tujuan penelitian untuk memperoleh gambaran tentang curah hujan bulanan maupun tahunan.

\section{Analisis Data}

Laju erosi. Model persamaan yang digunakan adalah persamaan umum kehilangan tanah atau USLE, dengan persamaan sebagai berikut :

$$
A=R \times K \times L S \times C \times P
$$

\section{Dengan pengertian bahwa :}

$$
\begin{array}{ll}
\mathrm{A} & =\text { Jumlah tanah hilang maksimun dalam ton/ha/tahun } \\
\mathrm{R} & =\text { Erosivitas hujan } \\
\mathrm{K} & =\text { Faktor erodibilitas tanah } \\
\mathrm{LS} & =\text { Indeks faktor panjang kemiringan lereng } \\
\mathrm{C} & =\text { Indeks pengelolaan tanaman } \\
\mathrm{P} & =\text { Indeks faktor tekhnik konservasi tanaman }
\end{array}
$$

Perhitungan nilai erosivitas hujan $(R)$ berdasarkan Bols (1978) yaitu :

$\mathrm{Rm}=6,119^{*}$ (Rain) ${ }^{1,21}$ (Days) $\mathrm{m}^{-0,47^{\star}}$. (Max $\left.\mathrm{P}\right) \mathrm{m}^{0,53}$

Dimana :

$\mathrm{Rm}=$ Erosivitas hujan bulanan rata-rata

(Rain) $\mathrm{m}=$ Jumlah curah hujan bulanan $(\mathrm{cm})$

(Days)m = Jumlah hari hujan bulanan rata-rata pada bulan tertentu

$(\operatorname{Max} \mathrm{P}) \mathrm{m}=$ curah hujan harian rata-rata maksimal pada bulan tertentu $(\mathrm{cm})$ 
Perhitungan nilai erodibilitas tanah (K) oleh Wischmeier (1971) dalam Utomo, W (1994) yaitu :

$$
K=\frac{2,7 M^{\prime 14}\left(10^{4}\right)(12-a)+2,5(C-3)}{100}
$$

Dimana :

$\mathrm{K}=$ Indeks erodibilitas tanah

$\mathrm{M}=$ = Parameter ukuran butir yang diperoleh dari :

a $=$ Persentase bahan organik $(\% \mathrm{C} \times 1,724)$

b $\quad=$ Kode struktur tanah (tabel 4 )

Perhitungan nilai faktor panjang dan kemiringan lereng (LS) dengan persamaan/rumus, yaitu :

LS $\quad=[\text { Panjang lereng / 22,1 }]^{m *}\left[0,00641 \mathrm{~S}^{2}+0,0456\right](4)$

Dimana :

$\mathrm{S}=$ Kemiringan dalam \%

$\mathrm{M}=0,5$ jika kemiringan lereng sama dengan $5 \%$ atau lebih

0,4 jika kemiringan lereng $3,5-4,5 \%$

0,3 jika kemiringan lereng $1-3 \%$

0,2 jika kemiringan lereng lebih kecil dari $1 \%$

Nilai faktor $\mathrm{C}$ dapat diketahui melalui penelusuran hasil penelitian dan pengecekan lokasi yang meliputi kondisi penutupan tajuk, penutupan permukaan lahan usahatani secara keseluruhan,apakah berupa semak dan serasah.

$$
I B E=\frac{\text { A. }(\text { ton } / \text { ha/thn }}{T S L \text { ton/ha/thn }}
$$

Klasifikasi indeks bahaya erosi menurut Hammer : (1981) adalah sebagaimana tabel 11 .

Kriteria dan indikator kinerja DAS perlu ditentukan dalam penyelenggaraan pengelolaan DAS. Karena keberhasilan maupun kegagalan hasil kegiatan pengelolaan DAS dapat dimonitor dan dievaluasi melalui kriteria dan indikator yang telah ditetapkan.

Kriteria penilaian erosi menurut Departemen Kehutanan (2000) dikenal dengan indeks erosi (IE), yaitu perbandingan antara erosi aktual dengan TSL. Jika IE $<1$, maka kriterianya baik, sebaliknya IE > 1, adalah jelek.

a. Erosi yang diperkenankan

Penentuan erosi yang diperkenankan atau disebut nilai $\mathrm{T}$, didasarkan pada sifat tanah dan substratumnya seperti yang tercantum di dalam tabel berikut ini :

Tabel 13. Pedoman Penetapan Nilai T Untuk Tanah-Tanah di Indonesia 


\begin{tabular}{|c|c|}
\hline Sifat Tanah dan Substratum & $\begin{array}{c}\text { Nilai T } \\
\text { (mm per } \\
\text { tahun) }\end{array}$ \\
\hline 1. Tanah sangat dangkal di atas batuan .. & 0.0 \\
\hline $\begin{array}{l}\text { 2. Tanah sangat dangkal di atas bahan telah melapuk (tidak } \\
\text { terkonsolidasi) } \ldots \ldots \ldots \ldots \ldots \ldots \ldots \ldots\end{array}$ & 0.4 \\
\hline Tanah dangkal di atas bahan telah melapuk & 0.8 \\
\hline Tanah dengan kedalaman sedang telah melapuk & 1.2 \\
\hline Tanah yang dalam dengan lapisan dalam & 1.4 \\
\hline 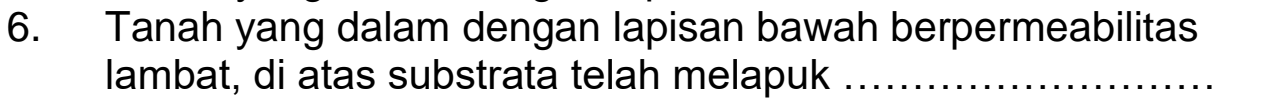 & 1.6 \\
\hline $\begin{array}{l}\text { 7. Tanah yang dalam dengan lapisan bawahnya berpermeabilitas } \\
\text { sedang, di atas substrata telah melapuk }\end{array}$ & 2.0 \\
\hline $\begin{array}{l}\text { 8. Tanah yang dalam dengan lapisan bawah yang permeable } \\
\text { diatas }\end{array}$ & 2.5 \\
\hline
\end{tabular}

Sumber : Arsyad, 1989

\section{HASIL DAN PEMBAHASAN}

\section{A. Prediksi Erosi}

\section{Unit Lahan Usahatani}

Unit lahan usahatani merupakan suatu kesatuan lahan yang arealnya relatif seragam atas sejumlah faktor penentu erosi. Unit lahan diperoleh berdasarkan hasil penetapan orientasi dari berbagai pola usaha yang ada di Desa Kabiraan. Hasil orientasi tersebut ditetapkan sejumlah 6 (enam) pola usahatani yang masing-masing mempunyai karakteristik yang berbeda seperti komposisi jenis penyusun dan derajat kemiringan.

Keenam unit lahan pola usahatani ini dijadikan satuan lahan dalam analisis selanjutnya. Karakteristik komponen pembentuk setiap unit lahan usahatani ditunjukkan pada tabel 18.

\section{Laju Erosi}

Erosi adalah peristiwa pindahnya atau terangkutnya tanah atau bagian-bagian tanah dari suatu tempat ke tempat lain oleh media alam.alju erosi dalam penelitian ini dihitung dengan menggunakan USLE (Universal Soil Loss Equation). Berdasarkan nilainilai faktor penyebab erosi sesuai persamaan USLE dalam menduga besarnya laju erosi setiap unit lahan ditunjukkan pada tabel 26 besarnya erosi yang terjadi pada 6 (enam) lahan pola usahatani dapat dihitung dengan menggunakan nilai dari faktorfaktor, erovitas (R) erodibilitas (K), panjang dan kemiringan lereng (LS), faktor tanaman (C), dan konservasi tanah (P). Berdasarkan nilai dari faktor-faktor (RKLSCP), maka besarnya erosi yang terjadi pada 6 (enam) pola usahatani adalah 99,30 ton/ha/tahun. Berdasarkan keenam pola usahatani, maka besarnya laju erosi pada setiap bentuk pola yaitu jagung, kacang tanah 45.36 ton/ha/tahun; Cengkeh, pulio, cempaka, kemiri, durian, tippulu, langsat, semak sebesar 16,37 ton/ha/tahun; jagung, ubi kayu sebesar 
10.96 ton/ha/tahun; pisang, durian, semak, coklat, gamal, kapok, mangga, rumput sebesar 8.18 ton/ha/tahun; dan jagung, Gamal sebesar 4.34 ton/ha/tahun.

Tabel 23. Besarnya erosi potensial dan aktual pada 6 (enam) unit lahan pola usahatani di Desa Kabiraan.

\begin{tabular}{|c|c|c|c|c|c|c|c|c|}
\hline \multirow[b]{2}{*}{$\begin{array}{l}\text { No } \\
\text { Plot }\end{array}$} & \multirow[b]{2}{*}{ Pola Usahatani } & \multirow[b]{2}{*}{$\mathbf{R}$} & \multirow[b]{2}{*}{ K } & \multirow[b]{2}{*}{ LS } & \multirow[b]{2}{*}{ C } & \multirow[b]{2}{*}{$\mathbf{P}$} & \multicolumn{2}{|c|}{ Erosi } \\
\hline & & & & & & & $\begin{array}{c}\text { Potensial } \\
\left(R^{\star} K^{\star} L S\right) \\
\text { ton/ha/tahun }\end{array}$ & $\begin{array}{c}\text { Aktual } \\
\left(R^{\star} K^{\star} L S^{*} C P\right) \\
\text { ton } / \text { ha/tahun }\end{array}$ \\
\hline 1. & $\begin{array}{l}\text { Jagung, kacang } \\
\text { tanah }\end{array}$ & 2436,48 & 0,38 & 0,07 & 0,45 & 1 & 64.81 & 45.36 \\
\hline 2. & Jagung,Ubi kayu & 2436,48 & 0,38 & 0,08 & 0,195 & 1 & 72.11 & 14.06 \\
\hline 3. & $\begin{array}{l}\text { Coklat, gamal, } \\
\text { jambu, durian, enau } \\
\text { mangga }\end{array}$ & 2436,4 & 0,45 & 0,05 & 0,2 & 1 & 54.82 & 10.96 \\
\hline 4. & $\begin{array}{l}\text { Pisang,durian, } \\
\text { semak, coklat, } \\
\text { gamal, kapok, } \\
\text { mangga, rumput }\end{array}$ & 2436,48 & 0,21 & 0,08 & 0,2 & 1 & 40.94 & 8.18 \\
\hline 5. & $\begin{array}{l}\begin{array}{l}\text { Cengkeh, } \\
\text { cempalio, } \\
\text { durian, }\end{array} \\
\text { kemiri, } \\
\text { langsat, semak }\end{array}$ & 2436,48 & 0,48 & 0,07 & 0,2 & 1 & 81.86 & 16.37 \\
\hline 6. & Jagung, Gamal & 2436,48 & 0.34 & 0,05 & 0,7 & 0,15 & 41.42 & 1,34 \\
\hline
\end{tabular}

Penetapan batas tertinggi erosi yang masih dapat dibiarkan atau ditoleransikan (Tolerable Soil Loss) keenam unit lahan pola usahatani Desa Kabiraan ditunjukkan dalam Tabel 24.Sedang nilai erosi yang diperkenankan untuk keenam pola usahatani tersebut yaitu antara 0,8 sampai 2,0 ton/ha/tahun. Penetapan batas tertinggi laju erosi yang masih dapat dibiarkan adalah penting, karena tidak mungkin menekan laju erosi menjadi noldari tanah yang diusahakan untuk pertanian terutama tanah yang berlereng.

Dengan adanya batas tertinggi laju erosi yang masih dapat dibiarkandalam suatu unit lahan, maka kedalaman tanah akan terpelihara yang cukup bagi pertumbuhan tanaman untuk mencapai produktivitas yang tinggi secara lestari.

Evaluasi akhir dari erosi potensial dinyatakan dalam indeks bahaya (ancaman) erosi yang dihitung dengan persamaan :

$$
I B E=\frac{\text { A. }(\text { ton } / \text { ha/thn }}{T S L \text { ton/ha/thn }}
$$

Dimana : TSL adalah besarnya erosi yang masih dapat dibiarkan.

Tabel 24. Nilai Indeks Bahaya Erosi (IBE) keenam unit lahan pola usahatani di Desa Kabiraan. 


\begin{tabular}{|c|c|c|c|c|c|}
\hline \multirow[t]{2}{*}{$\begin{array}{l}\text { Pola } \\
\text { Tanam }\end{array}$} & \multirow[t]{2}{*}{ Kombinasi Tanaman } & \multirow[t]{2}{*}{$\begin{array}{l}\text { Erosi potensial } \\
\text { (ton/ha/tahun) }\end{array}$} & \multirow[t]{2}{*}{$\begin{array}{c}\text { TSL } \\
\text { (ton/ha/tahun) }\end{array}$} & \multicolumn{2}{|c|}{$\begin{array}{c}\text { Indeks Bahaya Erosi } \\
\text { Erosi Potensial } \\
\text { TSL }\end{array}$} \\
\hline & & & & Nilai & Harkat \\
\hline $\mathrm{A}$ & Jagung, kacang tanah & 64.81 & 0,8 & 62,78 & sangat tinggi \\
\hline $\mathrm{B}$ & Jagung, Ubi kayu & 72.11 & 2,0 & 187,16 & sangat tinggi \\
\hline C & $\begin{array}{l}\text { Coklat, gamal, jambu Durian, } \\
\text { enau }\end{array}$ & 54.82 & 0,8 & 37,03 & sangat tinggi \\
\hline D & $\begin{array}{l}\text { Pisang, durian, semak, coklat, } \\
\text { gamal, kapok,mangga,rumput }\end{array}$ & 40.94 & 2,0 & 191,02 & sangat tinggi \\
\hline$E$ & $\begin{array}{l}\text { Cengkeh, pulio, cempaka, } \\
\text { kemiri, durian, tippulu, langsat, } \\
\text { semak }\end{array}$ & 81.86 & 1,6 & 128,25 & sangat tinggi \\
\hline $\mathrm{F}$ & Jagung, Gamal & 41.42 & 0,8 & 35,05 & sangat tinggi \\
\hline
\end{tabular}

\section{a. Nilai Kesenjangan (GAP)}

Berdasarkan hasil perhitungan erosi aktual dan erosi diperkenankan pada 6 (enam) pola usahatani di Desa Kabiraan, terdapat nilai kesenjangan, nilai kesenjangan dapat diperoleh apabila nilai erosi actual lebih besar dari erosi diperkenankan, seperti ditunjukkan pada tabel 25.

Tabel 25. Nilai kesenjangan pada berbagai pola usahatani di Desa Kabiraan

\begin{tabular}{|c|c|c|c|c|}
\hline $\begin{array}{l}\text { Pola } \\
\text { Tanam }\end{array}$ & Kombinasi Tanaman & $\begin{array}{l}\text { Erosi Aktual (A) } \\
\text { (ton/ha/thn) }\end{array}$ & $\begin{array}{c}\text { Erosi } \\
\text { Diperkenankan } \\
\text { (T) (ton/ha/thn) }\end{array}$ & $\begin{array}{c}\text { Kesenjangan } \\
\text { (GAP) } \\
\text { (ton/ha/Thn) }\end{array}$ \\
\hline A & Jagung, kacang tanah & 54.91 & 0,8 & $-54,11$ \\
\hline B & Jagung, Ubi kayu & 18.24 & 2,0 & $-16,24$ \\
\hline C & $\begin{array}{l}\text { Coklat, gamal, jambu, } \\
\text { durian, enau, mangga }\end{array}$ & 9.25 & 0.8 & $-8,45$ \\
\hline $\mathrm{D}$ & $\begin{array}{l}\text { Pisang, durian, semak, } \\
\text { coklat, gamal, kapok, } \\
\text { mangga, rumput }\end{array}$ & 19.10 & 2,0 & $-17,1$ \\
\hline$E$ & $\begin{array}{l}\text { Cengkeh, pulio, cempaka, } \\
\text { kemiri, durian, tippulu, } \\
\text { langsat, semak }\end{array}$ & 16.03 & 1,6 & $-14,43$ \\
\hline $\mathrm{F}$ & Jagung, Gamal & 30.69 & 0,8 & $-29,89$ \\
\hline
\end{tabular}

\section{b. Rumusan Tindakan Konservasi}

Berdasarkan hasil analisis kesenjangan (GAP) pada 6 (enam) pola usahatani di Desa Kabiraan,semua pola usahatani perlu mendapat berbagai tindakan konservasi (Vegetative, Mekanik), agar erosi yang terjadi pada setiap pola usahatani lebih kecil dari erosi yang diperkenankan, rumusan tindakan konservasi keenam pola usahatani ditunjukkan pada Tabel 26.

Tabel 26. Rumusan tindakan konservasi pada berbagai pola usahatani di Desa Kabiraan

\begin{tabular}{|c|c|c|c|c|}
\hline \multirow[b]{2}{*}{$\begin{array}{l}\text { Pola } \\
\text { tanam }\end{array}$} & \multirow[b]{2}{*}{ Kombinasi Tanaman } & \multicolumn{2}{|l|}{ Tindakan } & \multirow{2}{*}{$\begin{array}{l}\text { Tindakan } \\
\text { Vegetasi }\end{array}$} \\
\hline & & Fisik & $\begin{array}{c}\text { Nilai } \\
\text { Faktor }\end{array}$ & \\
\hline$A$ & Jagung, Kacang tanah & $\begin{array}{l}\text { - Pemb. Teras bangku } \\
\text { - Pemberian mulas jagung } \\
\text { - } \text { Pemberian mulas } \\
\text { Kacang tanah }\end{array}$ & $\begin{array}{l}0,15 \\
0,35 \\
0,75\end{array}$ & $\begin{array}{l}\text { - Pemb. Tanaman } \\
\text { ubi kayu } \\
\text { - Penanaman gamal }\end{array}$ \\
\hline
\end{tabular}




\begin{tabular}{|c|c|c|c|c|}
\hline $\mathrm{B}$ & Jagung, Ubi kayu & $\begin{array}{l}\text { - } \text { Kontur cropping } \\
\text { Strip rumput permanen (baik, } \\
\text { rapat, dan berjalur) }\end{array}$ & $\begin{array}{l}0,90 \\
0,04\end{array}$ & $\begin{array}{l}\text { - Penanaman } \\
\text { kacang tanah, } \\
\text { tanaman manggis }\end{array}$ \\
\hline C & $\begin{array}{l}\text { Coklat, gamal, jambu, } \\
\text { durian, enau, mangga }\end{array}$ & $\begin{array}{l}\text { - Strip rumput permanen } \\
\text { - Strip crotolaria }\end{array}$ & $\begin{array}{c}0,04 \\
0,5\end{array}$ & - Penanaman vanili \\
\hline $\mathrm{D}$ & $\begin{array}{l}\text { Pisang, durian, semak, } \\
\text { coklat, gamal, kapok, } \\
\text { mangga, rumput }\end{array}$ & - Kontur cropping & 0,90 & 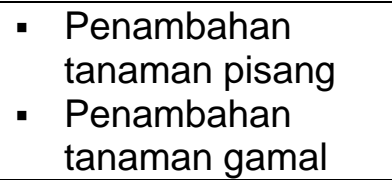 \\
\hline$E$ & $\begin{array}{l}\text { Cengkeh, pulio, } \\
\text { cempaka, gamal, kemiri, } \\
\text { durian, tippulu, langsat, } \\
\text { semak }\end{array}$ & - Pembuatan teras tradisional & 0,35 & $\begin{array}{l}\text { - Penambahan } \\
\text { tanaman kemiri } \\
\text { - Penambahan } \\
\text { tanaman cengkeh }\end{array}$ \\
\hline $\mathrm{F}$ & Jagung, gamal & $\begin{array}{l}\text { - Strip rumput permanen } \\
\text { - Pemberian mulas jagung }\end{array}$ & $\begin{array}{l}0,04 \\
0,35\end{array}$ & $\begin{array}{l}\text { - Penanaman } \\
\text { tanaman gamal } \\
\text { - Penanaman ubi } \\
\text { kayu }\end{array}$ \\
\hline
\end{tabular}

\section{B. KESIMPULAN DAN SARAN}

\section{A. Kesimpulan}

1. Besarnya laju erosi yang terjadi pada 6 (enam) pola usahatani di Desa Kabiraan sebesar 99,30 ton/ha/tahun, sedang besarnya nilai erosi yang di toleransikan atau di biarkan (Tolerable Soil Loss) pada masing-masing pola usahatani yaitu antara 0,8 sampai 2,0 ton/ha/tahun.

2. Berdasarkan faktor tanaman dan komposisi jenis penyusun pola usahatani, maka komposisi jenis penyusun berupa jagung, kacang tanah merupakan penyumbang erosi terbesar di lahan-lahan usahatani Desa Kabiraan yaitu 45.36 ton/ha/tahun, yang kemudian berturut-turut pisang, durian, semak, coklat, gamal, kapok, mangga, rumput sebesar 19.10 ton/ha/tahun; jagung, ubi kayu sebesar 14.06 ton/ha/tahun; Cengkeh, pulio, cempaka, kemiri, durian, semak, coklat, gamal, kapok, mangga, rumput sebesar 19.10 ton/ha/tahun; jagung, ubi kayu sebesar 14.06 ton/ha/tahun; Cengkeh, pulio, cempaka, kemiri, durian, tippulu, langsat, semak sebesar 16.37 ton/ha/tahun; Coklat, gamal, jambu, durian, enau, mangga sebesar 9.25 ton/ha/tahun dan Jagung, Gamal sebesar 4.60 ton/ha/tahun. Jagung, gamal merupakan penyumbang erosi terkecil, karena disamping memiliki jarak tanaman rapat juga memiliki bangunan teras tradisional.

3. Berdasarkan hasil analisis kesenjangan (GAP) pada 6 (enam) pola usahatani perlu mendapat berbagai tindakan khusus konservasi (kondisi fisik, konsisi vegetasi). rumusan tindakan konservasi masing-masing pola usahatani untuk tindakan fisik yaitu pola jagung, kacang tanah, tindakan fisiknya (pembuatan teras bangku, pemberian mulsa jagung, mulsa kacang tanah); pola jagung ubi kayu, tindakan fisiknya (kontur cropping, strip rumput permanen); pola coklat, gamal, jambu, durian, enau, mangga, tindakan fisiknya (strip rumput permanen, strip crotolaria): pola pisang, durian, semak, coklat, gamal, kapok, mangga, rumput tindakan fisiknya 
(kontur cropping); pola cengkeh, pulio, cempaka, kemiri,durian, tippulu, langsat, semak, tindakan fisiknya (pembuatan teras tradisional); pola jagung, gamal tindakan fisiknya (strip rumput permanen, pemberian mulsa jagung).

4. Semua pola usahatani perlu mendapat tindakan vegetasi yang di setujui oleh para petani (penambahan jenis tanaman yang sama, penanaman jenis lain)

B. Saran

1. Besarnya erosi yang terjadi pada 6 (enam) pola usahatani di Desa Kabiraan, semua pola usahatani menghasilkan besarnya erosi melebihi erosi diperkenankan, oleh karena itu kegiatan pemanfaatan lahan usahatani yang ada di Desa Kabiraan sudah harus diikuti dengan pratek-pratek konservasi tanah yang lebih baik.

2. Pola penggunaan lahan usahatani yang ada di Desa Kabiraan disarankan agar lebih berorientasi kepada bentuk penggunaan lahan pertanian hutan (agroforestry) yang dapat membentuk struktur tajuk yang bertingkat dan rapat serta penutupan lahan (land cover) yang baik, diantaranya pemanfaatan tumbuhan bawah. 


\section{DAFTAR PUSTAKA}

Arsyad, C., 2000. Konservasi Tanah dan Air.IPB Press, Bogor.

Asdak, 2002. Hidrologi dan Pengelolaan Daerah Aliran Sungai. Gadjah Mada Universitas Press. Yogyakarta.

BAPPEDA Kabupaten Majene, 2007. Laporan Sistem Informasi Lahan (SIL) Kabupaten Majene.

Basyar, Ahmad. 2006. Evaluasi Perubahan Perilaku Evolusi Daerah Aliran Sungai Citarum Hulu Dengan Permodelan Spasis.

http ://www.ftsl.itb.ac.id/wp-content/uploads/2007/04/art.74

125.153.132/search?q=cac he:sm.

Beasley,R.P. 1972. Erosion and Sediment Pollution Control, The lowa State University Press, Ames lowa.

Buckman, H.O.dan N.C. Brady, 1982 : Ilmu Tanah, Terjemahan Soegiman, Bhratara, Jakarta.

Clark II, Haverkamp \& Chapman, 1985 dalam Jumartina Sihite. 2001. Evaluasi Dampak Erosi Tanah. http ://72.14.235.132/Search?q=cache. Thjo.36obhmi: wvvw. Woridaqroforestry. Org/seaf publications/file.

Departemen Kehutanan, 1986.Pedoman Penyusunan Rencana Tekhnik Lapangan Rehabilitasi Lahan dan konservasi Tanah Daerah Aliran Sungai Citarum Hulu Dengan Pemodelan Spasis.

http ://www.ftsl.itb.ac.id/wp-content/uploads/2007/04/art.74

125.153.132/search?q=cac he:sm.

Beasley, R.P. 1972. Erosion and Sediment Pollution Control. The lowa State University Press, Ames lowa.

Buckman, H.O dan N.C. Brady, 1982: Ilmu Tanah. Terjemahan Soegiman. Bhratara,Jakarta.

Clark II, Haverkamp \& Chapman, 1985 dalam Jumartina Sihite. 2001. Evaluasi Dampak Erosi Tanah.

http://72.14.235.132/Search?q=cache.thjo.36obhmi:wvvw.woridagroforestry.org/seaf.pu blications/file.

Departemen Kehutanan, 1986. Pedoman Penyusunan Rencana Teknik Lapangan Rehabilitasi Lahan dan Konservasi Tanah Daerah Aliran Sungai. Direktorat Jendral Reboasasi dan Rehabilitasi Lahan, Jakarta.

Hammer, W.I. 1981. Final Soil Conservation Consultant Report. Tech.Note No. 26 Centre For Soil Research, Bogor.

Hardjowigeno. 1987.IImu Tanah. PT. Medyatama Sarana Perkasa, Jakarta. Jansson, M.B. 1982. Land Erosion by Water in Different Cilmates. Departement of Physic. Geograph. Uppsala Univ. UNG/Rapport No.57, Sweden. 
Karama, ..... 1988. Potensi Dampak Pengembangan Pola Tanam.

http://pse.litbang.deptan.go.id/ind/pdf.files/FAE22-2d.pdf.

Karama dan Abdulrrachman.1995. Usaha Konservasi Tanah dan Air Sebagai Alternatif Peningkatan Pendapatan Petani di Lahan Kering (Kasus Konservasi Tanah dan Air di Desa Rejosari, Kecamatan Semin, Kabupaten Gunung kidul, Propinsi DIY).

http://ntb.litbang.deptan.go.id/2005/sp/usahakonservasi.doc.

Kasryno. 2003. Potensi Dampak Pengembangan Pola Tanam.

http://pse.litbang.deptan.go.id/ind/pdf.files/FAE2222-2d.pdf.

Koiman, A. 1987. The Factor C.International Institute for Surveys and Earth Sciences

(I.T.C) Landresources and Rural Development, Departement of Rural and Landecology Survey, Enschede, The Netherlands.

Morgan, R.P.C. 1979. Soil Erosion and Conservation Longman, London.

Nasiah, 2000. Evaluasi Kemampuan Lahan Dan Tingkat Bahaya Erosi Untuk Prioritas Konservasi Lahan Di Daerah Aliran Sungai Takapala Dati II Gowa Propinsi Sulawesi

Selatan. Tesis program pasca sarjana.UGM Yogyakarta. 